\title{
Transport of Tracers and Pollutants From the Geysers Geothermal Resource Area
}

M. M. Orgill

R. N. Lee

R. I. Schreck

August 1983

Prepared for the U.S. Department of Energy under Contract DE-AC06-76RLO 1830

Pacific Northwest Laboratory Operated for the U.S. Department of Energy by Battelle Memorial Institute 
DISCLAIMER

This report was prepared as an account of work sponsored by an agency of the United States Government. Neither the United States Government nor any agency thereof, nor any of their employees, makes any warranty, express or implied, or assumes any legal liability or responsibility for the accuracy, completeness, or usefulness of any information, apparitus, product, or process disclosed, or represents that its use would not infringe privately owned rights. Reference herein to any specific commercial product, process, or service by trade name, trademark, manufacturer, or otherwise, does not necessarily constitute or imply its endorsement, recommendation, or favoring by the United States Government or any agency thereof. The views and opinions of authors expressed herein do not necessarily state or reflect those of the United States Government or any agency thereof.

\section{PACIFIC NORTHWEST LABORATORY operated by BATTELLE for the UNITED STATES DEPARTMENT OI: ENERGY under Contract DE-AC06-76RLD 1830}

Printed in the United States of Ameri t: Available from

National Technical Information Servire United States Department of Commerce 5285 Port Royal Road Springfield, Virginia 22161

NTIS Price Codes Microfiche A01

Printed Copy 
Transport of Tracers and

Pollutants from the Geysers

Geotherma1 Resource Area
M. M. Orgill
R. N. Lee
R. I. Schreck

August 1983

Prepared for the U.S. Department of Energy under Contract DE-AC06-76RLO 1830

Pacific Northwest Laboratory

Richland, Washington 99352 
. 


\section{ACKNOWLEDGEMENTS}

The authors wish to express their appreciation to the late P.W. Nickola formerly of Pacific Northwest Laboratory (PNL) for his dedicated efforts in siting and monitoring the surface hi-volume samplers, to R.V. Hannigan (PNL) in completing the aircraft sampling flights in a professional manner, and to J.S. Wetzel (formerly of PNL) and D.E. Mollenberndt (Environmental Systems and Services) for collecting the rawinsonde data. 
. 


\section{SUMMARY}

A limited surface and aircraft sampling study was conducted in the Geysers Geothermal Resource Area to collect initial data on the short-range (5 to $20 \mathrm{~km}$ ) transport of tracer and pollutant materials from this geothermal electrical power generation area. The sampling study was accomplished during the DOE ASCOT Cooling Tower field program in August 1981 as part of the daytime limited mixing experiments.

An initial analysis of $\mathrm{SF}_{6}$ tracer data from the Geysers illustrates the importance that terrain, vertical wind shear, time-varying winds and stability can have on the downwind distribution of cooling tower effluents during the daytime. Atmospheric stability (neutral to unstable) and near surface winds above $3 \mathrm{~m} / \mathrm{s}$ results in fumigation and surface impaction of a portion of cooling tower plumes on downwind surfaces and terrain. Vertical wind shear and possible gravity waves in upper-levels ( $1800-2000 \mathrm{~m}$ m.s.1), in addition, to terrain influences assist in distributing plumes horizontally and in the vertical at relative short $(210-20 \mathrm{~km})$ distances from the source.

Small quantities of gaseous sulfur, primarily $\mathrm{H}_{2} \mathrm{~S}$, are transported up to $20 \mathrm{~km}$ or more from the Geysers area. A variety of trace materials such as sulfate, copper, zinc, arsenic, bromine, lead, antimony, selenium and barium appear to be enriched over background levels and transported downwind from the Geysers Area at times. Future work will expand and further quantify these results. 
. 


\section{CONTENTS}

Page

1. INTRODUCTION

2. EXPERIMENTAL DESIGN

2.1 SITE DESCRIPTION . . . . . . . . . 3

2.2 INSTRUMENTATION

2.2.1 Surface Equipment . . . . . . 3

2.2.2 Aircraft Instrumentation . . . . 5

2.3 EXPERIMENTAL PROCEDURES

2.4 SYNOPTIC WEATHER PATTERN . . . . . . . 7

3. RESULTS AND DISCUSSION • . . . . . . . . 11

$3.1 \mathrm{SF}_{6}$ TRACER TRANSPORT FROM THE GEYSERS . • • 11

3.2 GASEOUS SULFUR $\left(\mathrm{H}_{2} \mathrm{~S}\right)$ TRANSPORT FROM THE GEYSERS 14

3.3 COMPOSITION, ENRICHMENT AND TRANSPORT OF

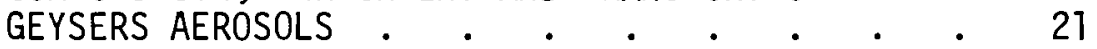

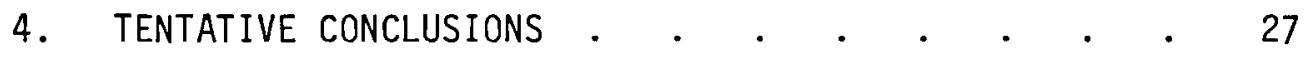

REFERENCES • • • • • • • • • • • • • 29 


\section{FIGURES}

$\underline{\text { Page }}$

1 Geographic Setting of the Geysers-Calistoga Geothermal

Resource Area (GGRA), the Geysers, and Location of Aircraft

Sampling Flights and Surface Hi-Volume Filter Samplers

2 Horizontal Wind Direction and Speed as a Function of Height and Time as Derived from Rawinsonde Observations for August 20,21, 23, and 24, 1982 at Sawmill Flats

3 Units 9 and 10 Geothermal Power Plant and Cooling Tower Plume $\mathrm{SF}_{6}$ Tracer Release Site

$4 \quad \mathrm{SF}_{6}$ Bag Sample Site Locations, Integrated Surface Plume Boundary, Plume Arrival Hours (14 and 18 PST) and Duration of Plume at Surface (hrs). Source: Units 9 and 10 Date: August 24, 1981

$5 \quad \mathrm{SF}_{6}$ Elevated Plume as Determined from Aircraft 5-Second Average Concentrations. Elevation: $1120 \mathrm{~m}(3760 \mathrm{ft}) \mathrm{m} . \mathrm{s} .1$. Date: August 24, 1981

$6 \mathrm{SF}_{6}$ Elevated Plume as Determined from Aircraft 5-Second Average Concentrations. Elevation: $1300 \mathrm{~m}(4270 \mathrm{ft}) \mathrm{m} . \mathrm{s} .1$. Date: August 24,1981

$7 \quad \mathrm{SF}_{6}$ Elevated Plume as Determined from Aircraft 5-Second Average Concentrations. Elevation: $1580 \mathrm{~m}(5190 \mathrm{ft}) \mathrm{m} . \mathrm{s} .1$. Date: August 24, 1981

8 Transport of Gaseous Sulfur $\left(\mathrm{H}_{2} \mathrm{~S}\right)$ Plume from the Geysers as Depicted from Aircraft Sampfing August 20, 1981

9 Location of Gaseous Sulfur $\left(\mathrm{H}_{2} \mathrm{~S}\right)$ Plume in Relation to the Geysers as Depicted from Aircraft Sampling August 21, 1981 


\section{$\underline{\text { TABLES }}$}

Page

1 Surface $\mathrm{Hi}$-Volume Sampler Locations, Elevations, Average Flow Rates, and Averaged Total Air Sampled

2 Important Variables in the Transport and Diffusion of SF 6 from Units 9 and 10 August 24, 1981

3 Range of Average Maximum 20-sec Gaseous Sulfur $\left(\mathrm{H}_{2} \mathrm{~S}\right)$ Concentrations as a Function of Elevation for the Four Sampling Days

4 Trace Element Concentrations in Aircraft and Surface Samples Within and Downwind of the Geysers

5 Enrichment Factors Greater Than or Equal to 10 for Trace

Element Concentrations in Aircraft and Surface Samples Upwind, Within and Downwind of the Geysers 


\section{INTRODUCTION}

The emission, transport and dispersion of pollutants from energy production areas in complex landforms is a subject of continuing concern with respect to assessments on whether emitted pollutants may cause a significant impact on the general public and environment through the mechanisms of chemical reactions, impaction, dry deposition and acid precipitation.

A limited surface and aircraft sampling study was conducted in the Geysers-Calistoga Geothermal Resource Area (GGRA) to collect initial data on the short-range $(5$ to $20 \mathrm{~km}$ ) transport of pollutant materials and a sulfur hexafluoride $\left(\mathrm{SF}_{6}\right)$ tracer from this geothermal electrical power generation area. The electrical power generating capacity of the Geysers is undergoing extensive expansion. Power plant cooling towers and geothermal wells located on mountain ridges, slopes and valleys release a variety of emissions such as carbon dioxide $\left(\mathrm{CO}_{2}\right)$, hydrogen sulfide $\left(\mathrm{H}_{2} \mathrm{~S}\right)$, methane $\left(\mathrm{CH}_{4}\right)$, ammonia $\left(\mathrm{NH}_{3}\right)$, radon gas, arsenic $(\mathrm{As})$, boric acid $\left(\mathrm{H}_{3} \mathrm{BO}_{3}\right)$, mercury $(\mathrm{Hg})$ and other trace materials (Martin, et al. 1978). A current environmental issue in this area is the release of hydrogen sulfide and its transport to surrounding communities and agricultural areas. Since these emissions can result in an odor nuisance if concentrations exceed $30 \mathrm{ppb}$ (California Air Quality Standard) it is important to assess the transport and dispersion of the Geysers emissions to surrounding areas.

The Pacific Northwest Laboratory (PNL) sampling study was accomplished during the DOE ASCOT COOling Tower field program in August 1981 as part of the daytime 1 imited mixing experiments (Gudiksen, 1982). On August 23 and 24 , the ASCOT group conducted extensive meteorological and tracer experiments during the daytime hours. $\mathrm{A} \mathrm{SF}_{6}$ tracer was released from a power plant's cooling tower during the afternoon of each day. The $\mathrm{SF}_{6}$ tracer was sampled by a surface network of samplers and a Meteorology Research, Inc. (MRI) aircraft. The PNL aircraft flew a flight track between 5 to $20 \mathrm{~km}$ upwind and downwind of the Geysers while the MRI aircraft flew closer to the source over the Mayacmas ridge. In addition to these two days, the PNL aircraft also sampled for gaseous sulfur $\left(\mathrm{H}_{2} \mathrm{~S}\right)$ and airborne aerosols on August 20 and 21. 
The goals of the PNL study were four fold: a) to define the types and quantities of airborne materials such as $\mathrm{H}_{2} \mathrm{~S}, \mathrm{~B}, \mathrm{As}, \mathrm{Cd}, \mathrm{Pb}, \mathrm{Cr}$ and $\mathrm{Hg}$ that are emitted from the geothermal operations, b) collect data on the location, height and concentration of the airborne materials and $\mathrm{SF}_{6}$ tracer, $\mathrm{c}$ ) examine the role of vertical wind shear in the transport of the $\mathrm{H}_{2} \mathrm{~S}$ and $\mathrm{SF}_{6}$ tracer plumes and d) if possible, estimate the flux of pollutant material being transported from the Geysers.

The four-day study, although clearly insufficient to satisfy these four goals, nevertheless, was intended to provide initial data on the short-range ( 5 to $20 \mathrm{~km}$ ) transport of pollutants from an area source (The Geysers) in complex terrain. The purpose of this interim report is to discuss the initial data analysis and results in respect to the first three goals. Final analysis and conclusions will be reported in the future as an ASCOT report. 


\section{EXPERIMENTAL DESIGN}

\subsection{SITE DESCRIPTION}

The airborne and surface sampling was conducted over the GGRA located approximately $40 \mathrm{~km}$ north of Santa Rosa and about $65 \mathrm{~km}$ east of the Pacific Coast. Figure 1 shows the relative location of the GGRA and the major area of geotherma1 operations (The Geysers). The Geysers (shaded area in Figure 1) are located in the Mayacmas mountains which are oriented in a northwest-southeast direction. The Russian River valley lies to the west and Clear Lake lies to the north of the Geysers. Prominent mountain peaks in the area are Cobb Mountain $(1439 \mathrm{~m})$, Boggs Mountain $(1122 \mathrm{~m})$, Mt. St. Helena (1324 m), Mt. Hannah $(1212 \mathrm{~m})$ and Mt. Konocti $(1280 \mathrm{~m})$.

The ASCOT limited mixing experimental measurements were conducted in the Big Sulphur Creek valley, Anderson-Putah Creek valley and Cobb valley. The PNL sampling measurements extended the area of the ASCOT sampling measurements both east and west of the Geysers (Figure 1).

\subsection{INSTRUMENTATION}

\subsubsection{Surface Equipment}

Surface samplers were used to collect airborne aerosols during the same period that the aircraft was sampling overhead. Standard high-volume samplers were placed at seven different locations within and in the vicinity of the Geysers (Figure 1). Table 1 shows the range in elevations of the sampling sites. The location of the sampler sites were dictated by assessability and availability of power. The $D$ and $M$ Brangus Ranch site, al though not ideal, was selected as a surface background site because of its location--5 km southwest of the Geysers operations. 


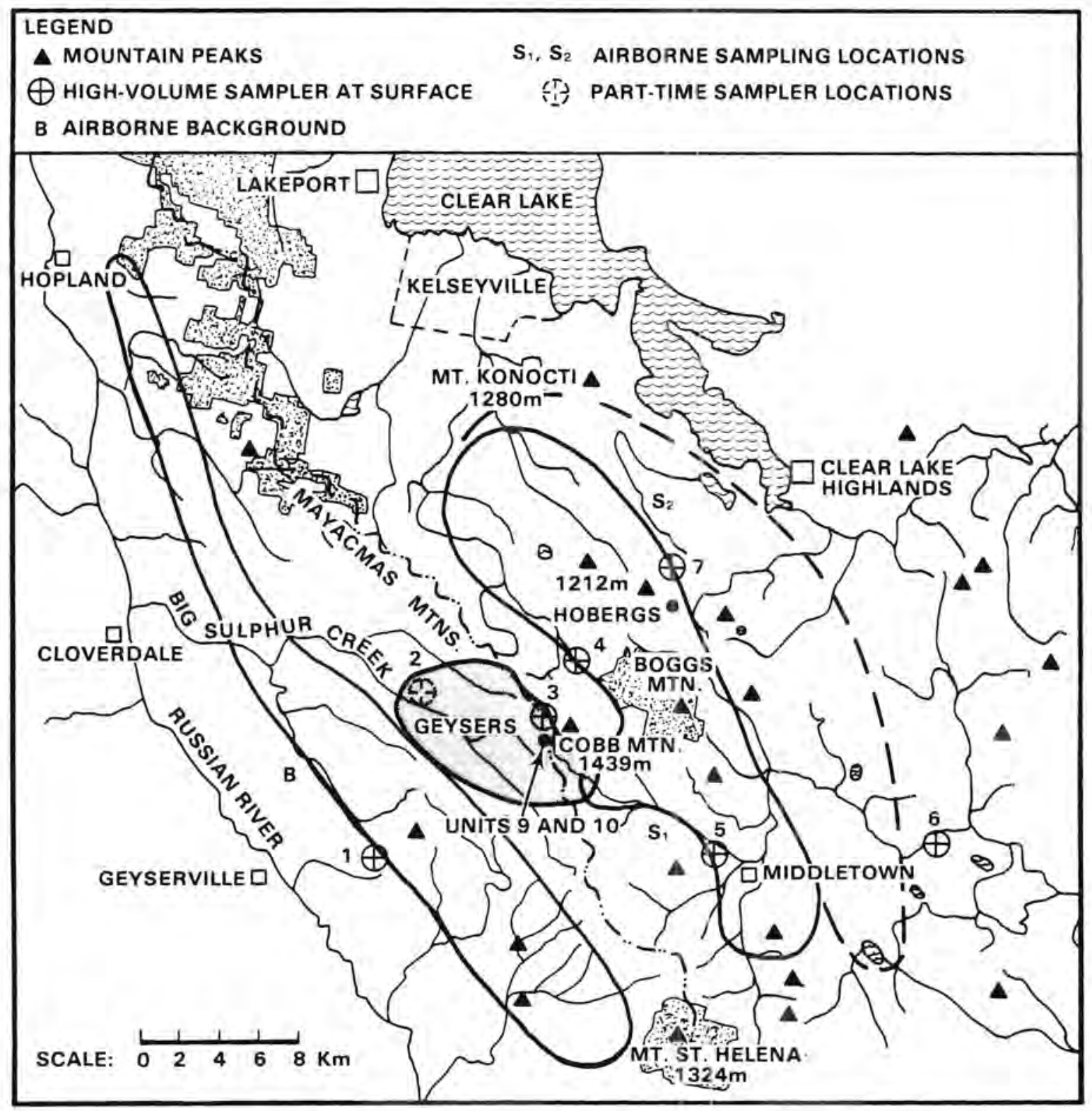

Figure 1. Geographic Setting of the Geysers-Calistoga Geothermal Resource Area (GGRA), the Geysers, and Location of Aircraft Sampling Flights and Surface Hi-Volume Filter Samplers. 
TABLE 1. Surface Hi-Volume Sampler Locations, Elevations, Average Flow Rates and Average Total Air Sampled

\begin{tabular}{|c|c|c|c|}
\hline Sampler Site & $\begin{array}{l}\text { Elevation } \\
\text { m m.s. } 1 \text {. }\end{array}$ & $\begin{array}{c}\text { Average Flow } \\
\text { Rate }_{3} \text { (per day) } \\
\mathrm{m}^{2} / \mathrm{min}\end{array}$ & $\begin{array}{l}\text { Average Total } \\
\text { Air Sampled } \\
\text { (per day) m }\end{array}$ \\
\hline $\begin{array}{l}\text { 1. D and M Brangus Ranch } \\
\text { 2. Administration Center* } \\
\text { 3. Repeater (Geysers Rock) } \\
\text { 4. Sawmill Flat } \\
\text { 5. Delfino (Middletown) } \\
\text { 6. Loran } \\
\text { 7. Lilla Ranch }\end{array}$ & $\begin{array}{r}591 \\
671 \\
1116 \\
722 \\
341 \\
439 \\
731\end{array}$ & $\begin{array}{l}0.54 \\
0.49(2) \\
0.47 \\
0.47 \\
0.46 \\
0.53 \\
0.50(2)\end{array}$ & $\begin{array}{l}198 \\
163 \\
172 \\
176 \\
165 \\
188 \\
158\end{array}$ \\
\hline
\end{tabular}

*Moved after two days to Lilla Ranch

The flow rate of each sampler was calibrated and set at approximately $0.50 \mathrm{~m}^{3} / \mathrm{min}$. Each sampler was monitored at the beginning and end of each experimental period. Table 1 shows the average flow rate and total air sampled per day for the different sampler locations.

The Whatman No. 41 filters used in the high-volume samplers had an exposed area of $52.8 \mathrm{~cm}^{2}(\mathrm{dia}=8.2 \mathrm{~cm})$. These filters are a tightly woven cellulose that causes the filter flow rate to decrease due to dust loading but, were chosen because of their cleanness with respect to trace element impurities.

A PNL rawinsonde located at Sawmill Flats provided upper-level data on temperature, humidity and winds at selected time periods during the four days of sampling. During the last two days, a PNL tethersonde collected temperature, humidity and wind data up to $500 \mathrm{~m}$. Other meteorological and sampling data are available from the ASCOT 1 imited mixing experiment.

\subsubsection{Aircraft Instrumentation}

The aircraft sampling was conducted with the PNL Cessna 411 aircraft which was equipped with the following measurement and sampling systems: a PNL rea1-time $\mathrm{SF}_{6}$ analyzer, real-time sulfur analyzer (Meloy SA285), an ozone 
monitor (Bendix 8002), a MRI integrating nephelometer, and a high-volume filter sampler.

Atmospheric state parameters which were measured included air temperature, dewpoint and pressure altitude. Geographic coordinates (1atitude, longitude) were obtained from a Global (GNS-500A) navigation system. These data and the real-time air quality and tracer data were recorded by a magnetic tape data acquisition system. The real time data of the $\mathrm{SF}_{6}$, sulfur and ozone was also monitored by strip-chart.

The filters used in the airborne high-volume sampler were Zefluor membrane filters with an exposed surface area of $21.2 \mathrm{~cm}^{2}(\mathrm{dia}=5.2 \mathrm{~cm})$. Flow rates varied from .11 to $.28 \mathrm{~m}^{3} / \mathrm{min}$. The filters have an extremely high collection efficiency and Tow impurity Tevels for trace elements.

\subsection{EXPERIMENTAL PROCEDURES}

The general flight procedure was to obtain airborne background measurements in the morning hours just west of the Geysers at approximately $1050 \mathrm{~m}$ and $1550 \mathrm{~m}$ (m.s.1.). In the afternoon, the $\mathrm{H}_{2} \mathrm{~S}$, aerosol, and $\mathrm{SF}_{6}$ sampling was conducted east (and downwind) of the Geysers between $1000 \mathrm{~m}$ and $1900 \mathrm{~m}$. Exceptions to this flight procedure occurred on August 20 when the procedure was reversed, and on August 21 when the background was taken in the early afternoon before sampling east of the Geysers.

The principal sampling transects, shown in Figure 1, were 5 to $12 \mathrm{~km}$ from the Units 9 and 10 power plant within the Geysers. These transects were flown in a race track manner at three different altitudes for an hour or more for each altitude. Each transect was flown from three to five times except for a transect at 18-20 km which was flown once. On August 21 and 23 the majority of sampling took place east of Boggs Mountain on a northwest to southeast flight track.

The range of altitudes and distances for sampling $\mathrm{H}_{2} \mathrm{~S}$ and $\mathrm{SF}_{6}$ in real-time was limited by the altitude sensitivity of the real-time samplers (baseline response varies with pressure) and the sampling of aerosols. The 
aerosol measurements required flying on a fixed path and altitude for a minimum of one hour in order to collect sufficient material for analysis.

The surface-based high-volume samplers were turned on at the beginning of the aircraft flight and operated continuously 7 to 8 hours, sufficient time to coincide with the aircraft sampling.

\subsection{SYNOPTIC WEATHER PATTERN}

The synoptic and weather conditions during the four days of sampling were determined by the subtropical high pressure area off the California-Oregon coast and a deep, winter-like low pressure area in the northern part of the Gulf of Alaska. Between August 20 and 22, a ridge of high pressure on the Oregon-California coast induced a weak onshore pressure gradient and caused an influx of marine air into the GGRA, mainly in the afternoons. After August 22, the cold front from the Gulf of Alaska low pressure area had moved to the Washington coast and became quasi-stationary near Vancouver Island. During this period a thermal low, developed in California and moved northward into Oregon. By August 23, the thermal low had moved northward and joined a developing low pressure system near Vancouver Island, a spin-off from the Gulf of Alaska low pressure system. On August 24, this new low pressure system and a weak cold front moved inland into northern Washington. The surface front trailed southward through Oregon and northern California resulting in a slight cooling trend. With the passage of the weak front, the ridge of high pressure along the Oregon-California coast intensified resulting in an increased depth and persistence of the marine layer inland.

Al1 afternoons of the sampling days were essentially cloudless. Extensive morning marine stratus was present over the GGRA on August 23 but this cloud layer was dissipated by noon. The weak frontal passage during August 24 caused a few widely scattered and poorly developed fair weather cumulus over the northern mountain peaks in the afternoon.

Figure 2 shows a time series of the available rawinsonde winds up to $2000 \mathrm{~m}$ for the four sampling days. Most all aircraft sampling flights were conducted during southwesterly to northwesterly upper-level winds. Wind 


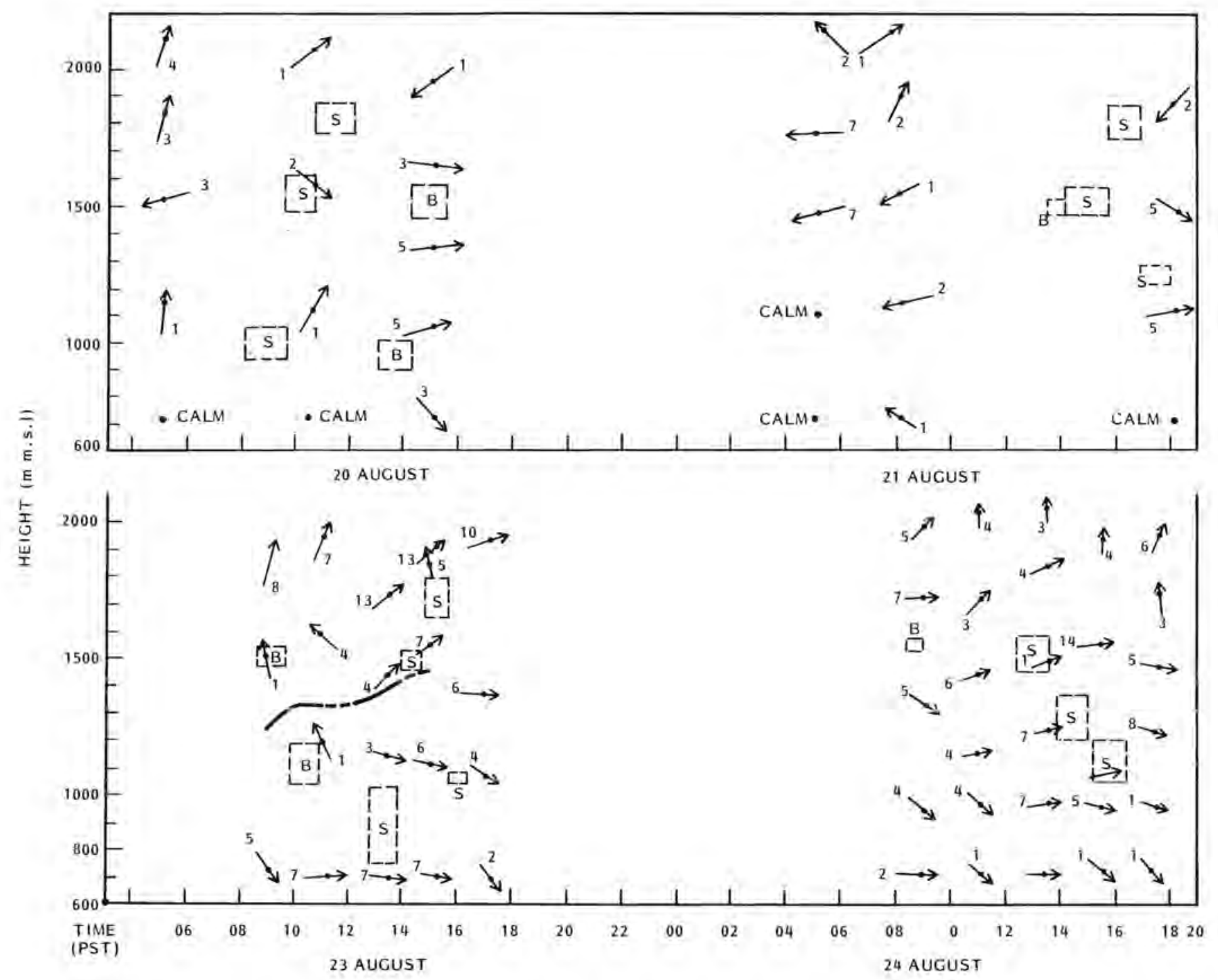

Figure 2. Horizontal Wind Direction and Speed $(\mathrm{m} / \mathrm{s})$ as a Function of Height and Time as Derived from Rawinsonde Observations for August 20, 21, 23 and 24, 1982 at Sawmill flats. Aircraft sampling heights and times represented by dashed boxes. B - background; S - sampling. 
speeds varied from 1 to $14 \mathrm{~m} / \mathrm{sec}$. During August 20 and 21 , the upper-1eve1 winds were variable in direction and speeds were between 1 to $5 \mathrm{~m} / \mathrm{sec}$.

Temperature soundings taken in the experimental area by the rawinsonde and ASCOT tethersondes indicated an elevated temperature inversion on August 23. The depth of the inversion increased from $1200 \mathrm{~m}$ to $1500 \mathrm{~m}$ (m.s.1.) between 1000 PST and 1700 PST. No significant inversions were present in the afternoon hours during the other three days. Substantial afternoon heating caused afternoon temperatures at the Sawmill site to vary from $25^{\circ} \mathrm{C}$ to $32^{\circ} \mathrm{C}$. Maximum temperature on August 24 was $6^{\circ} \mathrm{C}$ cooler than that of August 23.

Clear air turbulence at flight levels was insignificant al though temperature soundings indicated that moderate convective mixing should have been present over the GGRA on all afternoons. 


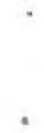




\section{RESULTS AND DISCUSSION}

\section{1 $\mathrm{SF}_{6}$ TRACER TRANSPORT FROM THE GEYSERS}

On August 23 and 24 , a $\mathrm{SF}_{6}$ tracer was released from Units 9 and 10 power plant cooling tower at a rate of $3 \mathrm{gm} / \mathrm{s}$ from 1300 PST to 1900 PST. Units 9 and 10 are located on a ridge southwest of Cobb Mountain at an altitude of $968 \mathrm{~mm} . \mathrm{s} .1$. (Figure 3 ). Since analysis is not complete, only preliminary results from August 24 will be discussed. However, August 23 was similar in many respects to August 24 . Table 2 outlines some of the variables considered important in the transport of the cooling tower plume and $\mathrm{SF}_{6}$ on August 24. The meteorological conditions were not very ideal but typical of many situations involving wind shear and time-varying wind conditions.

TABLE 2. Important Variables in the Transport and Diffusion of $\mathrm{SF}_{6}$ From Units 9 and 10, August 24, 1981

Variable

1. Plume rise

2. Stability

3. Low Tevel wind speeds

4. Horizonta1 and vertica1 wind shear

5. Diurnal winds

6. Terrain influences
Comments

Average maximum plume rise around $1100 \mathrm{~m}$ or $2060 \mathrm{~m} \mathrm{m.s.1.} \mathrm{(Uthe,} \mathrm{1982).}$ $\mathrm{SF}_{6}$ detected on the surface downwind from Units 9 and 10.

Average wind speeds in a $350 \mathrm{~m}$ layer 3 to $5 \mathrm{~m} / \mathrm{s}$.

Winds were backing and increasing in speed with height.

Winds in lower elevations changed direction from west-southwest to west-northwest. Possible gravity waves at higher elevations?

The wind and stability conditions were apparently favorable for a portion of the cooling tower plume to impact at downwind locations. Figure 4 shows a portion of the plume was observed at the surface throughout the Anderson-Putah Creek area and Boggs Mountain. The plume impaction occurred toward the northeast in the early afternoon and then shifted toward the southeast later in the afternoon. This change in direction of the surface impaction matches 


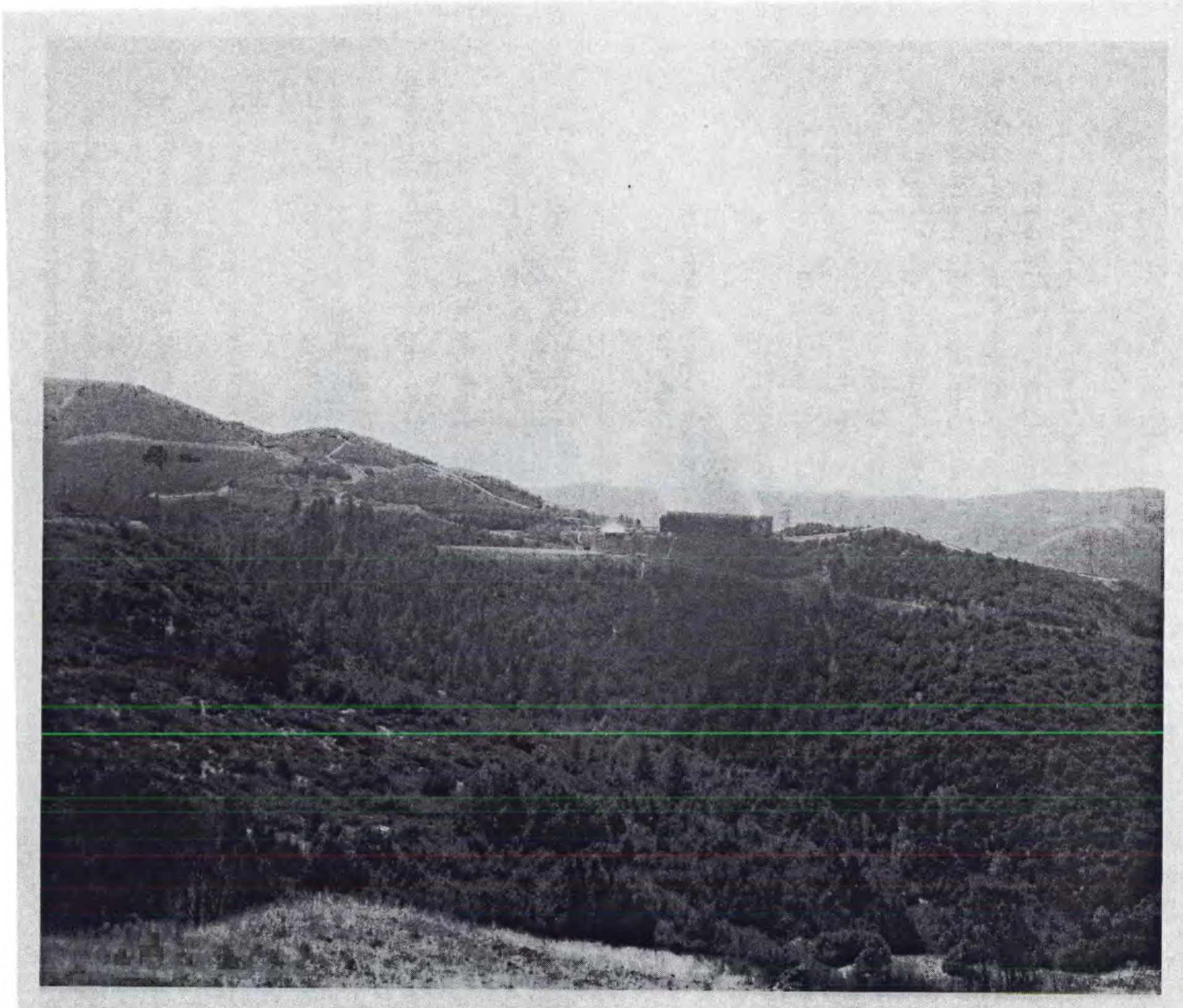

Figure 3. Units 9 and 10 Geothermal Power Plant and Cooling Tower Plume SF 6 Tracer Release Site. 


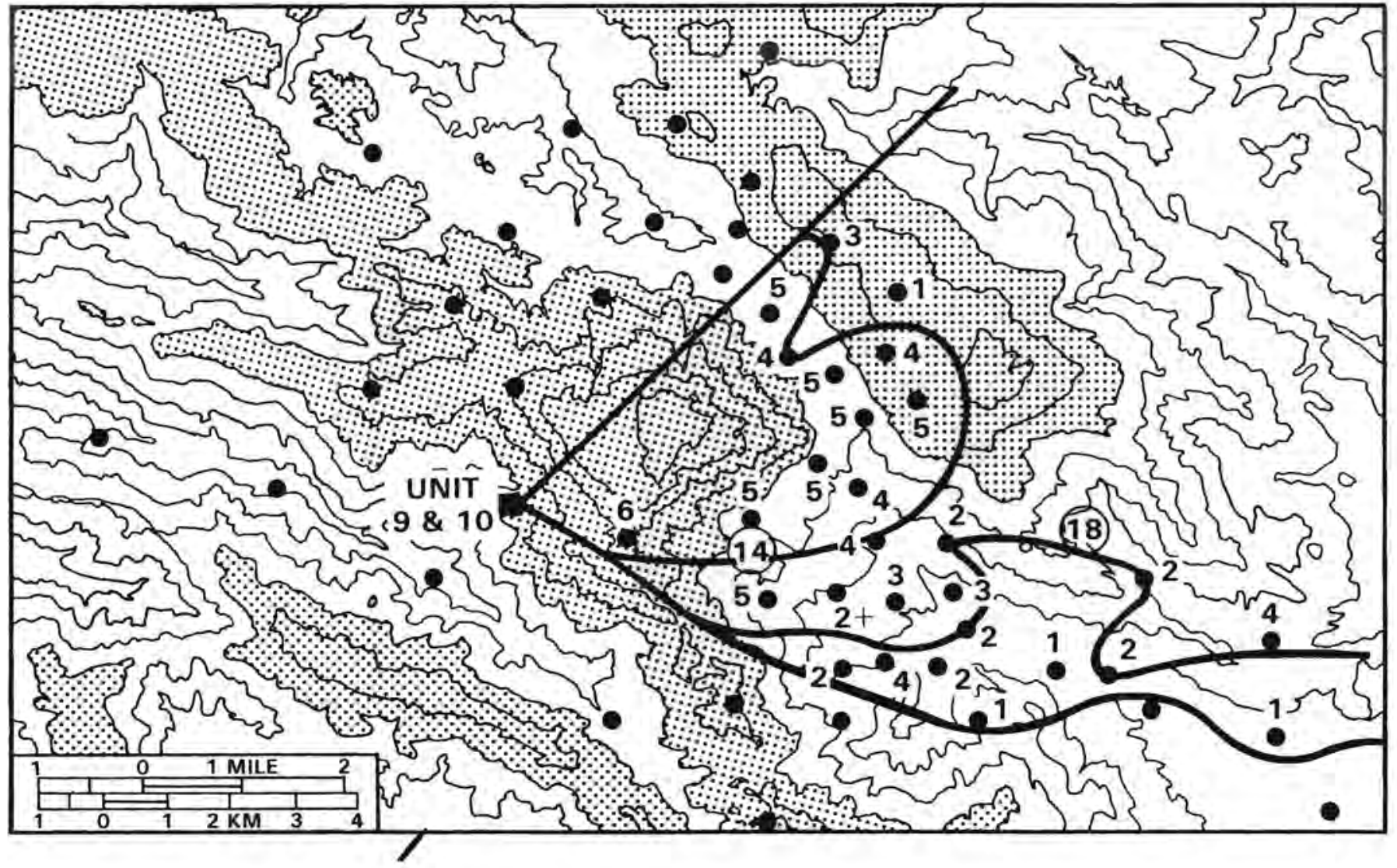

Figure 4. $\mathrm{SF}_{6}$ Bag Sample Site Locations, Integrated Surface Plume Boundary, Plume Arrival Hours (14 and 18 PST) and Duration of Plume at Surface (hrs) Source: Units 9 and 10, August 24, 1981. Shaded Topography $\geq 853 \mathrm{~m}(2800 \mathrm{ft})$. 
some wind observations that showed wind direction changing to more northwesterly directions after 1700 PST.

The principal plume axis at the three different aircraft sampling altitudes were generally the same direction as shown near the surface i.e. toward the east and northeast (Figures 5-7). Maximum concentrations in the elevated plumes were above $200 \mathrm{ppt}$. An increase in altitude shows a more diffuse plume with secondary maxima toward Middletown and east to northeast of Mt. Hannah. The apparent maximum concentration near Mt. Hannah at around $1600 \mathrm{~m}$ is of interest because of the high plume rise and upper vertical wind shear present during the sampling period. Another interesting feature was revealed by the Stanford Research Institute (SRI) airborne 1idar. These measurements showed wavy undulations in the aerosol boundary layer at sampling altitudes (Uthe, 1982). The presence of gravity waves may be a possible reason for the secondary $\mathrm{SF}_{6}$ maximum just east of $\mathrm{Mt}$. Hannah but this possible connection will have to be investigated in more detail in the future as will other details of other sampling passes.

\subsection{GASEOUS SULFUR $\left(\mathrm{H}_{2} \mathrm{~S}\right)$ TRANSPORT FROM THE GEYSERS}

One of the primary pollutants from the Geysers is gaseous sulfur in the form of $\mathrm{H}_{2} \mathrm{~S}$ al though other states of gaseous sulfur can be present such as $\mathrm{SO}_{2}$. Surface and aircraft filter samples generally indicated sulfur (sulfate) enrichment above background Tevels in the collected aerosol. On the two days of $\mathrm{SF}_{6}$ release from Units 9 and 10 (August 23 and 24), a minor amount of gaseous sulfur was contributed to the Geysers sulfur plume by $\mathrm{SF}_{6}$. A low concentration but measurable gaseous sulfur plume was detected on all four days in the eastern quadrants from the Geysers since the winds were general1y from southwesterly to westerly directions. The range in maximum concentrations is shown in Table 3. A peak concentration of $41 \mathrm{ppb}$ was observed on August 20. A brief synopsis of each day's results follows. 


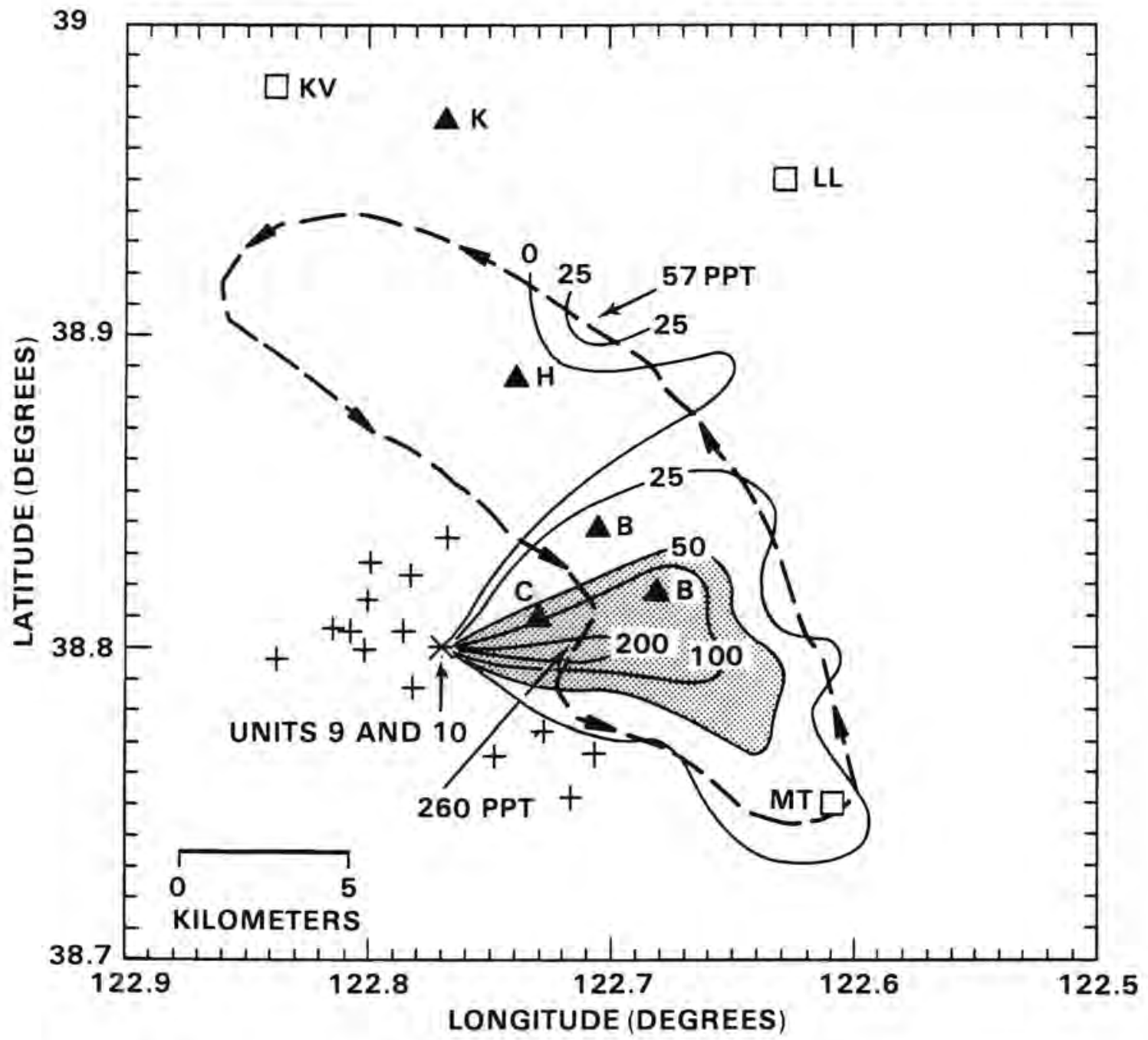

Figure 5. SF6 Elevated Plume as Determined from Aircraft 5-sec Average Concentration. Elevation: $1120 \mathrm{~m}(3670 \mathrm{ft}) \mathrm{m} . \mathrm{s} .1$. Locations: MT-Middletown, C-Cobb Mtn., H-Mt. Hannah, LL-Lower Lake, K-Mt. Kocnocti, KV-Kelseyville Date - August 24, 1981 


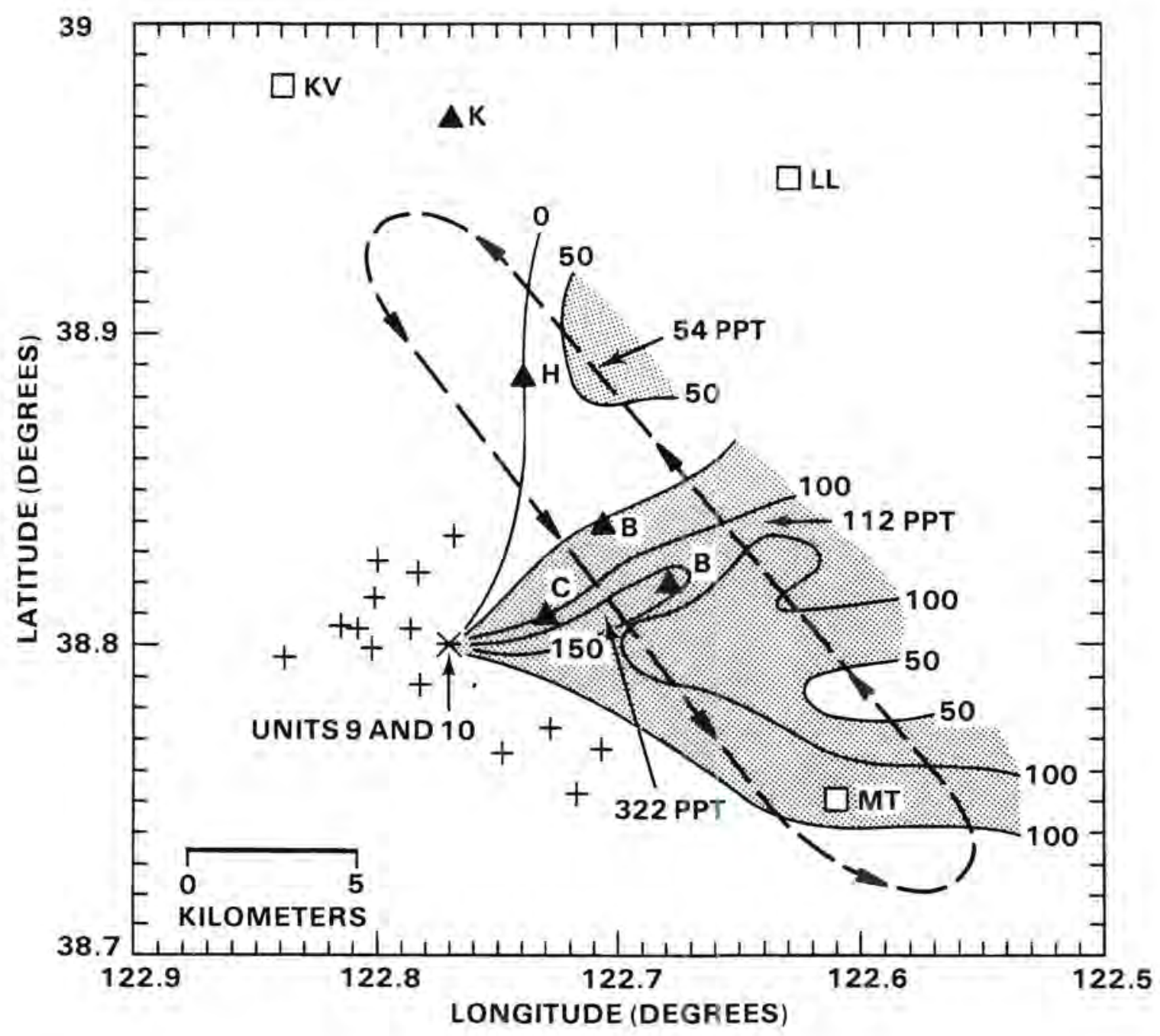

Figure 6. $\mathrm{SF}_{6}$ Elevated Plume as Determined from Aircraft 5-sec Average Concentration. Elevation: $1300 \mathrm{~m}(4270 \mathrm{ft}) \mathrm{m} \cdot \mathrm{s} .1$. Locations: MT-Middletown, C-Cobb Mtn., H-Mt. Hannah, LL-Lower Lake, K-Mt. Kocnocti, KV-Kelseyville, Date - August 24, 1981 


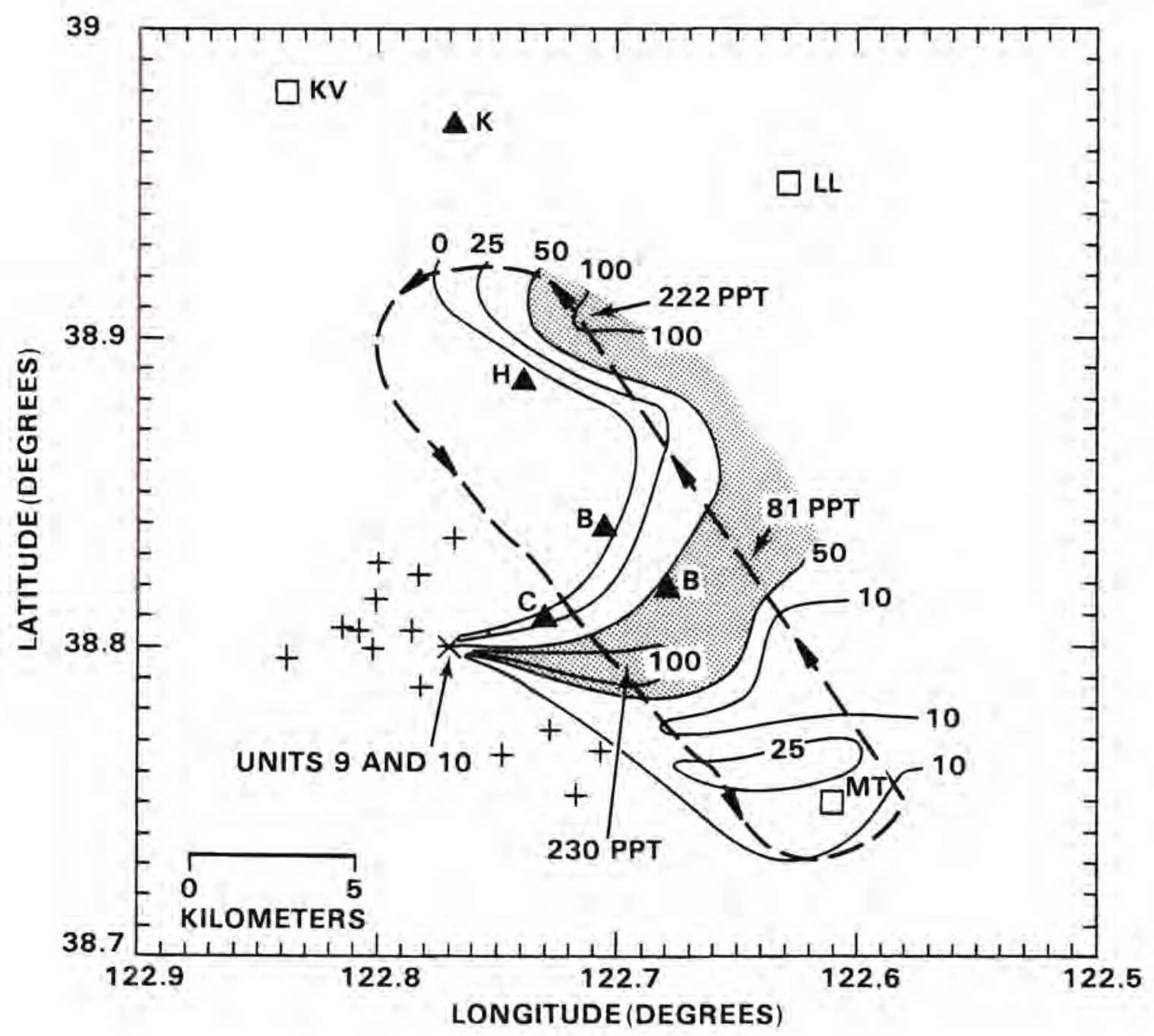

Figure 7. $\mathrm{SF}_{6}$ Elevated P1ume as Determined from Aircraft 5-sec Average Concentration. Elevation: $1580 \mathrm{~m}(5190 \mathrm{ft}) \mathrm{m} . \mathrm{s} .1$. Locations: MT-Middletown, C-Cobb Mtn., H-Mt. Hannah, LL-Lower Lake, K-Mt. Kocnocti, KV-Kelseyville, Date - August 24, 1981 
TABLE 3. Range of Average Maximum 20-sec Gaseous Sulfur $\left(\mathrm{H}_{2} \mathrm{~S}\right)$ Concentrations as a Function of Elevation for the Four Sampling Days (ppb)

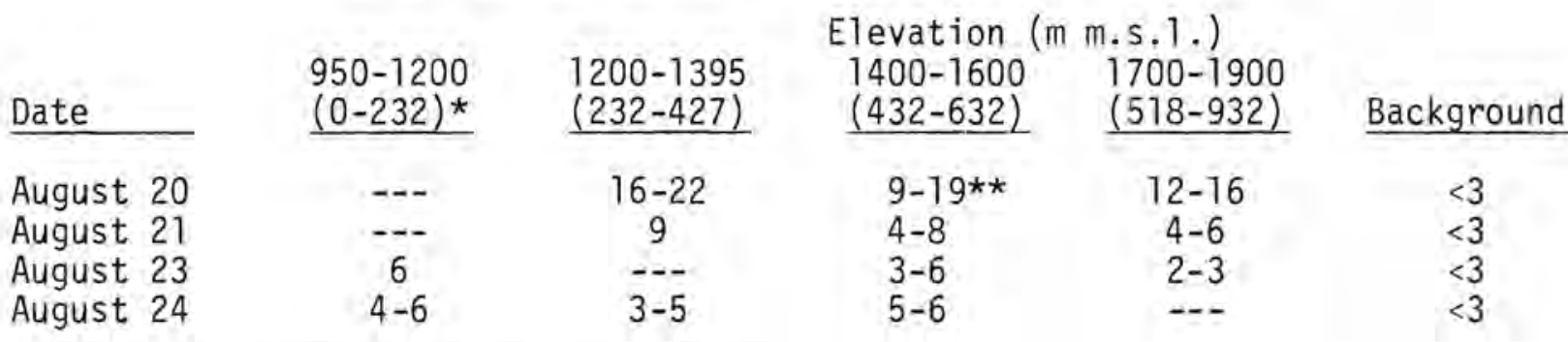

*Height above Units 9 and 10 in meters

**Peak concentration approximately $41 \mathrm{ppb}$

\section{August 20}

The plume was detected between 1200 and 1900 in and was found to be moving toward the north and northeast (Figure 8 ). Maximum concentrations varied between 9 and $22 \mathrm{ppb}$ at distances 5 to $12 \mathrm{~km}$ from the GGRA. A definite $\mathrm{H}_{2} \mathrm{~S}$ odor was detected in the aircraft at $1500 \mathrm{~m}$ about $4 \mathrm{~km}$ from the Geysers.

August 21

The plume was first detected to the southeast with maximum concentrations of about $9 \mathrm{ppb}$ and also to the east at lower concentrations (Figure 9). Concentrations were lower than on August 20 (Table 3 ). Later sampling to the east and northeast of the Geysers at elevations of $1500 \mathrm{~m}$ or more revealed an indistinct plume. Sampling in Cobb-Anderson Creek valley around $1200 \mathrm{~m}$ (m.s.1.) revealed an $\mathrm{H}_{2} \mathrm{~S}$ plume but concentrations were approximately half of those found on August 20 at the same altitude (Table 3).

August 23

The plume at and above $1500 \mathrm{~m}$ was narrow $(<5 \mathrm{~km})$, had low concentrations (Table 3) and was detected just east of Boggs Mountain (not shown). The plume below the temperature inversion was wider $(5$ to $10 \mathrm{~km})$, had higher concentrations and was detected east of Cobb Mountain $(\sim 7 \mathrm{~km})$. A shift of the plume axis to the north by 1 to $3 \mathrm{~km}$ in the higher elevations ( $1500 \mathrm{~m}$ to $1700 \mathrm{~m}$ ) correlates with an observed $50^{\circ}$ backing of the wind with height (Figure 2 ). 


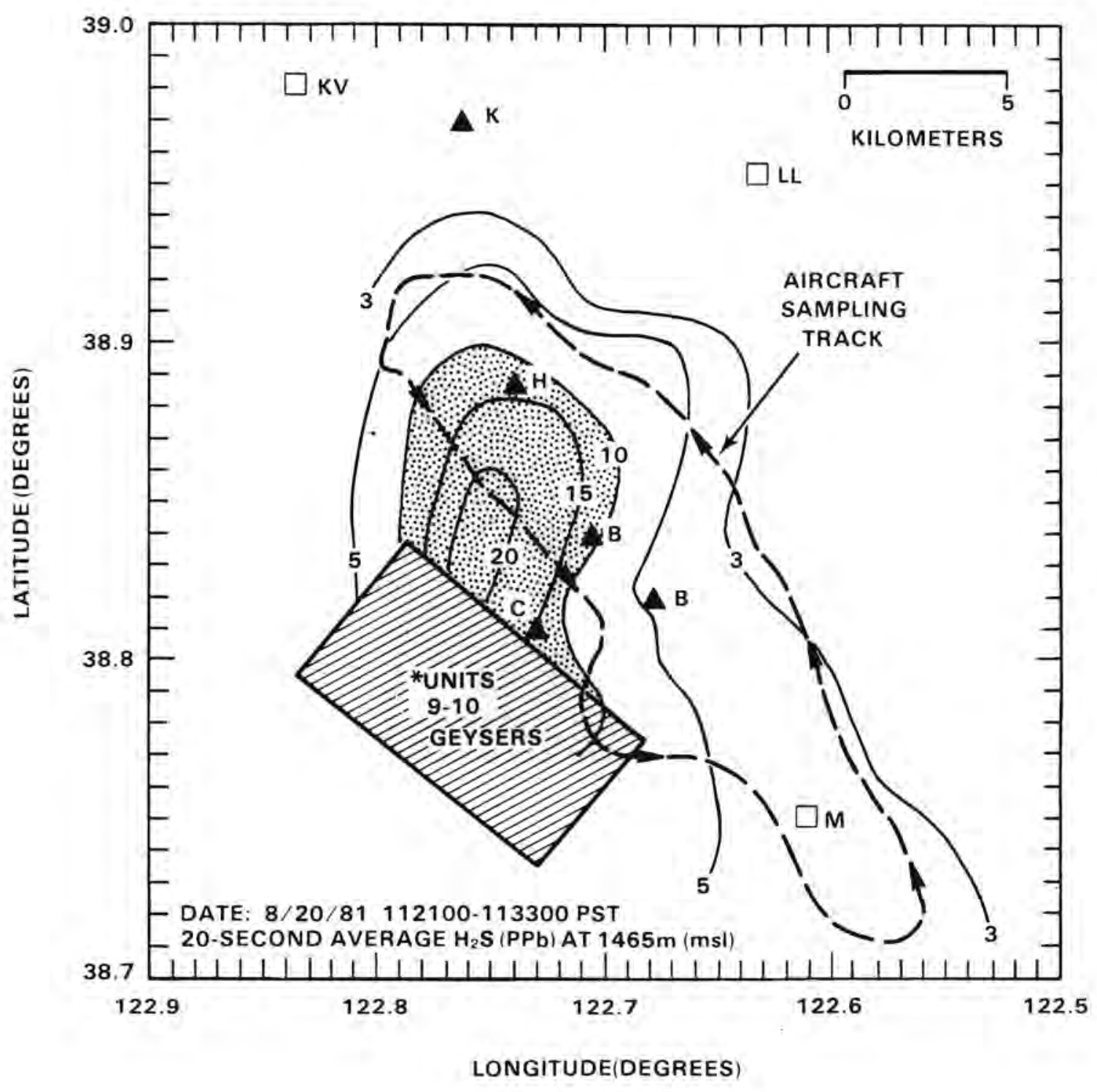

Figure 8. Transport of Gaseous Sulfur $\left(\mathrm{H}_{2} \mathrm{~S}\right)$ Plume from the Geysers as Depicted from Aircraft 20-sec Average Sampling Data 


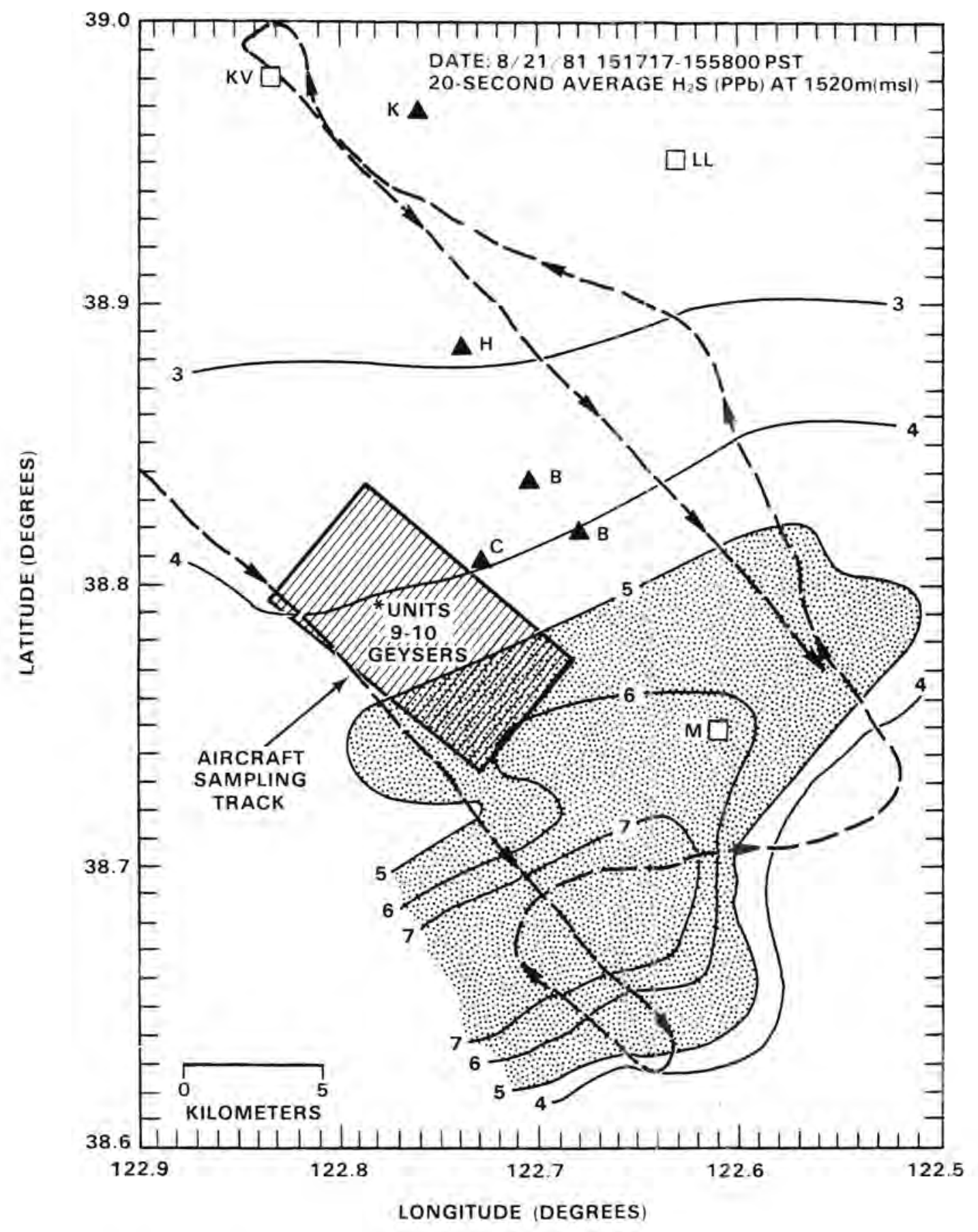

Figure 9. Location of Gaseous Sulfur $\left(\mathrm{H}_{2} \mathrm{~S}\right)$ Plume in Relation to the Geysers as Depicted from Aircraft 20-sec Average Sampling Data 


\section{August 24}

Plume concentrations were again lower than observed on August 20 but a measurable plume was detected to be moving to the east-northeast from the Geysers similar to the $\mathrm{SF}_{6}$ plume (not shown). A shift in the plume axis was apparently the result of the wind direction backing with height.

\subsection{COMPOSITION, ENRICHMENT AND TRANSPORT OF GEYSERS AEROSOLS}

The four days of sampling resulted in 41 filters. An initial selection of 23 filters ( 16 surface, 7 aircraft) was made for $x$-ray fluorescence (XRF) and neutron activation analysis (NAA) (23 by XRF; 8 by NAA). Concentrations were obtained for 55 trace materials. In general, most of the trace materials had concentrations in the $\mathrm{ng} / \mathrm{m}^{3}$ range with the exception of iron (Fe) and sulfur (S) which were in the $\mu \mathrm{g} / \mathrm{m}^{3}$ range (Table 4 ).

A crustal enrichment factor was computed for all 55 elements associated with the 23 filters. The crustal enrichment factor

$$
E F_{C}=\left(C_{x} / C_{F e}\right) \text { aerosol } /\left(C_{x} / C_{F e}\right) \text { crust }
$$

expresses the relative enrichment of an element as compared to its crustal abundance. An EF $c$ less than 1 indicates depletion of an element, whereas a value greater than 1 indicates enrichment of a given element relative to its crustal abundance. Generally, an enrichment factor of 10 or more is considered significant with respect to anthropogenic input to the atmosphere (Rahn, 1971). Table 5 shows the enrichment factors for various trace elements analyzed in the surface and aircraft filter samples. These results include all the surface stations shown in Tables 1 and 4 except the two most distant stations, Loran and Lilla Ranch.

Trace elements of particular interest because of their potential toxicity hazard and environmental contamination are sulfur (S), selenium (Se), boron $(B)$, bromine $(B r)$, lead $(\mathrm{Pb})$, zinc $(\mathrm{Zn})$, antimony (Sb), arsenic (As), barium $(\mathrm{Ba})$, silver $(\mathrm{Ag})$, cadmium $(\mathrm{Cd})$, copper $(\mathrm{Cu})$, manganese $(\mathrm{Mn})$, fluorine $(\mathrm{F})$ and mercury $(\mathrm{Hg})$. As Table 5 shows several of these elements were significantly enriched above background levels within and downwind of the Geysers area at 
TABLE 4. Trace Element Concentrations in Aircraft and 3 Surface Samples Upwind, Within and Downwind of the Geysers ( $\mathrm{ng} / \mathrm{m}^{3}$ ) (by XRF)

Element

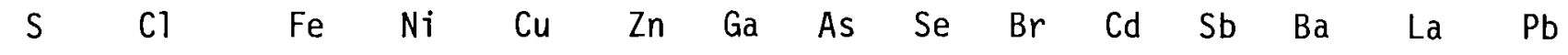

AIRCRAFT

\begin{tabular}{|c|c|c|c|c|c|c|c|c|c|c|c|c|c|c|}
\hline$Z F-33(B K)$ & 79 & * & 1076 & 6 & 5 & 12 & * & 5 & 5 & * & * & * & 65 & 406 \\
\hline$Z F-31$ & 159 & 8 & 1707 & 8 & 5 & 40 & * & 5 & * & $\star$ & $\star$ & 63 & 312 & 647 \\
\hline$Z F-18$ & 491 & * & 930 & 8 & * & 79 & * & 6 & 4 & 4 & $\star$ & 52 & 534 & 230 \\
\hline$Z F-38(B K)$ & 397 & * & 904 & 8 & 10 & 8 & 4 & 22 & $\star$ & $\star$ & $\star$ & * & * & * \\
\hline$Z F-26$ & 299 & 26 & 596 & 1 & $\star$ & 14 & 1 & 20 & $\star$ & $\star$ & $\star$ & 夫 & * & 99 \\
\hline$Z F-45$ & * & * & 715 & $\star$ & 38 & 30 & * & $\star$ & $\star$ & $\star$ & - & - & - & - \\
\hline$Z F-41$ & 158 & 38 & 403 & $\star$ & 13 & * & 2 & $\star$ & 9 & * & * & * & * & * \\
\hline
\end{tabular}

SURFACE

N

\begin{tabular}{|c|c|c|c|c|c|c|c|c|c|c|c|c|c|c|}
\hline $\begin{array}{l}B-20 \\
A-20 \\
R-20 \\
S-20\end{array}$ & $\begin{array}{r}609 \\
809 \\
1395 \\
1077\end{array}$ & $\begin{array}{l}305 \\
113 \\
251 \\
163\end{array}$ & $\begin{array}{l}4425 \\
1912 \\
8872 \\
2938\end{array}$ & $\begin{array}{l}22 \\
11 \\
32 \\
14\end{array}$ & $\begin{array}{r}148 \\
53 \\
545 \\
92\end{array}$ & $\begin{array}{l}26 \\
15 \\
47 \\
15\end{array}$ & $\begin{array}{l}\star \\
2 \\
3 \\
\star\end{array}$ & $\begin{array}{l}* \\
\text { * } \\
\text { * } \\
\text { * }\end{array}$ & $\begin{array}{l}\star \\
\star\end{array}$ & $\begin{array}{r}29 \\
6 \\
17 \\
9\end{array}$ & $\begin{array}{l}\star \\
\star \\
\star \\
\star\end{array}$ & $\begin{array}{l}\text { * } \\
\text { * } \\
\text { * } \\
\text { * }\end{array}$ & $x$ & $\begin{array}{l}\star \\
\star \\
\star \\
\text { * }\end{array}$ \\
\hline $\begin{array}{l}B-21 \\
A-21 \\
R-21 \\
S-21\end{array}$ & $\begin{array}{r}1049 \\
906 \\
1116 \\
977\end{array}$ & $\begin{array}{r}366 \\
165 \\
129 \\
54\end{array}$ & $\begin{array}{l}4320 \\
2257 \\
2894 \\
1272\end{array}$ & $\begin{array}{r}25 \\
12 \\
12 \\
6\end{array}$ & $\begin{array}{r}125 \\
27 \\
239 \\
79\end{array}$ & $\begin{array}{r}25 \\
16 \\
25 \\
8\end{array}$ & $\begin{array}{l}\star \\
2 \\
\star \\
\star\end{array}$ & $\begin{array}{l}\star \\
\text { * } \\
\text { * }\end{array}$ & $\begin{array}{l}* \\
\text { * }\end{array}$ & $\begin{array}{r}14 \\
7 \\
13 \\
9\end{array}$ & $\begin{array}{l}\text { * } \\
\star \\
\text { * } \\
\text { * }\end{array}$ & $\begin{array}{l}\text { * } \\
\text { * } \\
\text { * } \\
\text { * }\end{array}$ & 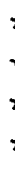 & $\begin{array}{l}* \\
+ \\
\star \\
\star\end{array}$ \\
\hline $\begin{array}{l}B-23 \\
R-23 \\
S-23 \\
D-23\end{array}$ & $\begin{array}{r}954 \\
1209 \\
1029 \\
656\end{array}$ & $\begin{array}{r}68 \\
214 \\
73 \\
127\end{array}$ & $\begin{array}{r}875 \\
1228 \\
617 \\
1008\end{array}$ & $\begin{array}{r}4 \\
5 \\
2 \\
15\end{array}$ & $\begin{array}{r}206 \\
233 \\
17 \\
1680\end{array}$ & $\begin{array}{r}10 \\
12 \\
6 \\
48\end{array}$ & $\begin{array}{l}\star \\
2 \\
\star \\
\text { * }\end{array}$ & $\begin{array}{l}\text { * } \\
\text { * } \\
\text { * }\end{array}$ & $\begin{array}{l}\star \\
\star \\
\star\end{array}$ & $\begin{array}{l}5 \\
8 \\
8 \\
4\end{array}$ & $\begin{array}{r}\text { * } \\
21 \\
\text { * } \\
\text { * }\end{array}$ & $\begin{array}{l}\text { * } \\
\text { * } \\
\text { * } \\
\text { * }\end{array}$ & , & $\begin{array}{l}\text { * } \\
\text { * } \\
\text { * }\end{array}$ \\
\hline $\begin{array}{l}B-24 \\
R-24 \\
S-24 \\
D-24\end{array}$ & $\begin{array}{r}302 \\
1091 \\
323 \\
416\end{array}$ & $\begin{array}{r}47 \\
291 \\
38 \\
252\end{array}$ & $\begin{array}{r}738 \\
9303 \\
787 \\
1007\end{array}$ & $\begin{array}{r}8 \\
35 \\
3 \\
25\end{array}$ & $\begin{array}{r}394 \\
188 \\
24 \\
4290\end{array}$ & $\begin{array}{r}13 \\
31 \\
9 \\
113\end{array}$ & $\begin{array}{l}* \\
4 \\
* \\
2\end{array}$ & $\begin{array}{l}\text { * } \\
\text { * } \\
\text { * } \\
\text { * }\end{array}$ & $\begin{array}{l}\text { * } \\
\text { * }\end{array}$ & $\begin{array}{r}\text { * } \\
13 \\
\text { * } \\
5\end{array}$ & $\begin{array}{r}* \\
48 \\
\star \\
\star\end{array}$ & $\begin{array}{l}\text { * } \\
\text { * } \\
\text { * } \\
\text { * }\end{array}$ & , & $\begin{array}{l}* \\
\star \\
* \\
*\end{array}$ \\
\hline
\end{tabular}


KEY TO TABLE 4:

\begin{tabular}{llcl} 
Aircraft & Date & $\begin{array}{c}\text { Elevation } \\
\text { (m m.S.1.) }\end{array}$ & Surface (see Table 1) \\
\cline { 2 - 3 } ZF-33 & August 20 & $945-1128$ & B - Brangus Ranch (background) \\
ZF-31 & August 20 & 1006 & A - Administration Center \\
ZF-18 & August 20 & $1494-1524$ & R - Repeater site \\
ZF-38 & August 21 & $1478-1524$ & S - Sawmi11 Flats \\
ZF-26 & August 21 & $1494-1524$ & D - Del Fino (Middletown) \\
ZF-45 & August 23 & $853-1066$ & \\
ZF-41 & August 24 & 1189 \\
& * - Concentrations near detection limit \\
& B - Missing Data &
\end{tabular}


TABLE 5. Enrichment Factors Greater Than or Equal to 10 for

Trace Element Concentrations in Aircraft and Surface Samples Upwind, Within and Downwind of the Geysers

$\begin{array}{lllllllllllllllllllllll}\mathrm{S} & \mathrm{Cl} & \mathrm{Ni} & \mathrm{Cu} & \mathrm{Zn} & \mathrm{Ga} & \mathrm{As} & \mathrm{Element} & \mathrm{Se} & \mathrm{Br} & \mathrm{Cd} & \mathrm{Sb} & \mathrm{Ba} & \mathrm{La} & \mathrm{Pb} & \mathrm{Hg} & \end{array}$

\section{AIRCRAFT}

\begin{tabular}{|c|c|c|c|c|c|c|c|c|c|c|c|c|c|c|}
\hline $\mathrm{ZF}-33(\mathrm{BK})$ & 16 & $\star$ & $<$ & $<$ & $<$ & * & 160 & 5750 & * & $\star$ & * & $<$ & 707 & * \\
\hline $2 F-31$ & 20 & $<$ & $<$ & $<$ & 19 & 夫 & 94 & * & * & $\star$ & 10370 & 24 & 711 & $<$ \\
\hline $2 F-18$ & 114 & $\star$ & $<$ & * & 68 & * & 195 & 4682 & 94 & $\star$ & 15800 & 76 & 464 & * \\
\hline$Z F-38(B K)$ & 95 & $\star$ & $<$ & 11 & $<$ & 15 & 745 & * & * & $\star$ & * & * & * & * \\
\hline$Z F-26$ & 109 & 19 & $<$ & * & 19 & $<$ & 1048 & $\star$ & * & $\star$ & * & * & 311 & * \\
\hline$Z F-45$ & $\star$ & $\star$ & * & 55 & 34 & $\star$ & $\star$ & * & * & - & - & - & - & * \\
\hline $2 F-41$ & 85 & 41 & * & 34 & $\star$ & 18 & $\star$ & 26560 & * & * & * & * & 夫 & * \\
\hline
\end{tabular}

SURFACE

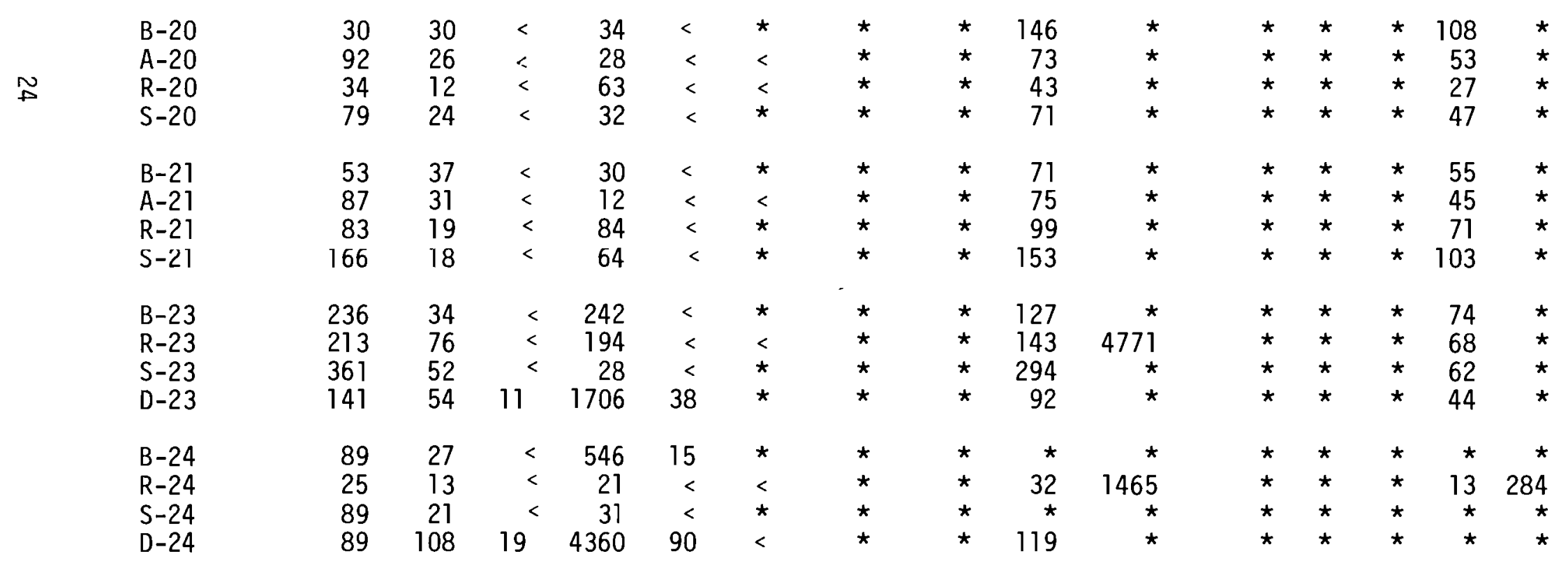

KEY: <-- Less than 10

* -- Concentration near detection limit

- -- Missing data 
times. However, their are a number of factors that need to be considered with respect to the collection and analysis of some elements. These are:

1) The surface samples showing $\mathrm{Cu}$ enrichment were probably contaminated by the high-volume samplers although precautions were taken to prevent it (Lynch et a1., 1980).

2) The aircraft sampling periods were limited by operational restrictions thus reducing the amount of material collected on filters. Less abundant element concentrations were therefore frequently near or below the respective detection limits.

3) Some of the elements may be associated with larger aerosols and thus fallout near the sources.

4) Some of the elements such as $\mathrm{Hg}, \mathrm{Br}$ and $\mathrm{As}$ have a gaseous component which was not sampled by filters (Robertson et a1., 1977, Moyers et a1., 1972, Grosch et a1. 1978). A possible example is the particulate $\mathrm{Br} / \mathrm{Pb}$ ratio, assuming that the automotive source (construction traffic, etc.) dominates the source for bromine and lead. The particulate $\mathrm{Br} / \mathrm{Pb}$ average ratios for surface and aircraft samples were 0.34 and 0.29 (upper 1 imit), respectively. These values are less than the ethyl fluid ratio of $\mathrm{Br} / \mathrm{Pb}$ $=0.39$ suggesting a possible loss of bromine to the gas phase.

5) Boron (B) a major element in geothermal steam, and fluorine ( $F$ ) have yet to be analyzed in the samples.

6) Some differences were noted between the NAA and XRF analysis. The NAA analysis showed significant enrichment $(>10)$ for arsenic in four surface samples that were not indicated by XRF analysis. Three of the aircraft filters that were analyzed by NAA showed little enrichment $(<10)$ for arsenic. NAA showed five surface samples enriched with antimony that were not indicated by XRF.

7) The high enrichment of cadmium for the repeater sites on August 23 and 24 may have been due to resuspended material as a result of construction activity near the site. However, the NAA results do not show any significant enrichment for cadmium these days. 
8) In general when one considers the enrichment above the possible background values in aircraft samples and at the surface the results appear a little inconsistent. However, the results do suggest that such elements as sulfate, copper, zinc, antimony, cadmium, selenium, mercury and arsenic may be transported from the Geysers at times. Lead, bromine and sulfate can be transported into the area from other sources but construction and vehicle activity at the Geysers can be sources for these materials as well. 


\section{TENTATIVE CONCLUSIONS}

This limited surface and aircraft sampling study in the Geysers area of California has extended the ASCOT study beyond the nighttime studies of nocturnal drainage winds of previous years. In this study the role of daytime synoptic-mesoscale winds in relation to the transport of pollutants from the total area of the Geysers has been examined. The four-day study, although clearly insufficient to define all the aspects of the transport problem for the Geysers nevertheless has provided initial data regarding the short-range transport of tracers and pollutants from the Geysers geothermal operations.

The initial analysis of the $\mathrm{SF}_{6}$ tracer transport data from the Geysers illustrates the importance that terrain, vertical wind shear, time-varying winds and stability can have on the downwind distribution of cooling tower effluents during the daytime. Atmospheric stability (neutral to unstable) and near-surface winds above $3 \mathrm{~m} / \mathrm{s}$ results in fumigation and surface impaction of a portion of cooling tower plumes on downwind surfaces and terrain. Vertical wind shear and possible gravity waves in upper levels ( 1800-2000 m m.s.1.), in addition to terrain influences assist in distributing plumes horizontally and in the vertical at relative short $(210-20 \mathrm{~km})$ distances from the source.

The surface and aircraft sampling revealed that small quantities of gaseous sulfur, primarily $\mathrm{H}_{2} \mathrm{~S}$, and a variety of trace materials may be transported from the Geysers area. In this study, only one day was observed to have gaseous sulfur concentrations above $30 \mathrm{ppb}$. On this day $\mathrm{H}_{2} \mathrm{~S}$ was detected as a distinct odor at $1500 \mathrm{~m}$ (m.s.1.) at around $4 \mathrm{~km}$ or more from the Geysers. Small quantities $\left(\mathrm{ng} / \mathrm{m}^{3}\right)$ of trace materials such as sulfur (sulfate), copper, zinc, arsenic, bromine, lead, antimony, selenium and barium appear to be enriched above background levels and are transported downwind from Geysers area. Future work is anticipated to complete the analysis of remaining data and to assist in quantifying and expanding the results. 


\section{REFERENCES}

Grosch, M., W. Grosch, G. Wolf and H. Kreyling, 1978. "Quantitative Analysis of Mercury, Arsenic and Bromine in Atmospheric Aerosols." Atmos. Environ., $12: 1235-1237$.

Gudiksen, P.H., 1982. ASCOT Data from the 1981 Cooling Tower Plume Experiments in the Geysers Geothermal Area. UCID-19332, ASCOT-82-4, Vols. 1 and 2, Lawrence Livermore National Laboratory, Livermore, California.

Lynch, A.J., N.R. McQuaker and D.F. Brown, 1980. "ICP/AES Analysis and the Composition of Airborne Soil Materials in the Vicinity of a Lead/Zinc Smelter Complex." JAPCA, 30(3):256-260.

Martin, J.B. et a1., 1978. Environmental, Safety and Health Standards Identification for Geothermal Energy. Report 1: Airborne Emissions. PNL-2583-1, Pacific Northwest Laboratory, Richland, Washington

Moyers, J.L., W.H. Zoller, R.A Duce and G.L. Hoffman, 1972. "Gaseous Bromine and Particulate Lead, Vanadium and Bromine in a Polluted Atmosphere." Environ. Sci. and Tech., 6(1):68-71.

Rahn, K.A., 1971. Sources of Trace Elements in Aerosols--An Approach to Clean Air. Ph.D. Thes is and Ann Arbor Report C00-1705-9, University of Michigan, Ann Arbor, Michigan.

Robertson, D.E., E.A. Crecelius, J.S. Fruchter and J.D. Ludwick, 1977.

"Mercury Emissions from Geothermal Power Plants." Science, 196(4294):10941097.

Uthe, E.E., 1982. Airborne Lidar Study of Plume Behavior in the Geysers Geothermal Area. UCID-19332, ASCOT-82-4, Vols. 1 and 2, Lawrence Livermore National Laboratory, Livermore, Cal ifornia. 
.

:

, 


\section{DISTRIBUTION}

No. of

Copies

OFFSITE

DOE Office of Health and Environmental Research Washington, DC 20545

27 DOE Technical Information Center

R.F. Abbey, Jr. Hydrology \& Meteorology Branch U.S. Nuclear Regulatory Commission

Bethesda, MD 20555

D.S. Ballantine

U.S. Department of Energy

Mai1 Stop E-74

Washington, DC 20545

Sumner Barr

Environmental Studies Group

MS-D466

Los Alamos National Laboratory

P.0. Box 1663

Los Alamos, NM 87544

James Bergen

RWU 1601

Pacific S.W. Forest and Range Experiment Station P.0. Box 245

Berkeley, CA 94701

Dr. G.E. Bertolin

Supervisor, Air Studies Rio Blanco 0 il Shale Company 2851 S. Parker Road

Aurora, CO 80014

Prof. A.K. Blackadar

Pennsylvania State University

Department of Meteorology

503 Walker Building University Park, PA 16802
No. of

Copies

Gary Briggs

Meteorology MD-80

U.S. Environmental Protection Agency

Research Triangle Park, NC 27711

Sue Bunker

Earth \& Space Sciences Div.

MS-F665

Los Alamos Scientific Laboratory P.0. Box 1663

Los A1amos, NM 87545

Hugh Church

Division 4533

Sandia Laboratory

P.0. Box 5800

A1buquerque, NM 87115

Mr. Cionco, Commander/Director

Atmospheric Laboratory

U.S. Army Electronics Command

DRLAS-VE-C

White Sands, NM 88002

Bi11 Clements

Earth \& Space Sciences Div.

Los Alamos Scientific Laboratory

Mai1 Stop D-466

P.0. Box 1663

Los Alamos, NM 87545

Richard Coulter

Atmospheric Physics Section

Argonne National Laboratory

9700 South Cass Avenue

Argonne, IL 60439

Cecil G. Davis

MS-D420 X-5

Los Alamos Scientific Laboratory P.0. Box 1663

Los Alamos, NM 87545 
No. of

Copies

5

5 M.H. Dickerson

$\mathrm{L}-262$

Lawrence Livermore National

Laboratory

P.0. Box 808

Livermore, CA 94550

C.R. Dickson

ARL Field Research Office

NOAA

550 Second Street

Idaho Falls, ID 83401

Rich Fisher

U.S. EPA, Region 8

1860 Lincoln Street

Denver, CO 80295

Mike Fosberg

U.S. Forest Service

Forest Fire Laboratory

4955 Canyon Crest Drive

Riverside, CA 92507

D.G. Fox

Rocky Mountain Forest and Range

Experiment Station

240 West Prospect Street

Ft. Collins, C0 80526

Dr. Walter Flood

U.S. Army Research office

ATTN : DRXRO-DP

P.0. Box 12211

Research Triangle Park, NC 27709

A1 Garrett

773A-1015

Savannah River Laboratory

E.I. du Pont de Nemours, Inc.

Aiken, SC 29808

Frank Gifford

Atmospheric Turbulence and

Diffusion Laboratory

NOAA

PO Box E

Oak Ridge TN 37830
No. of

Copies

Paul Gudiksen

$L-26 \imath$.

Lawrence Livermore National Latioratory

P.0. Box 808

Livermore, CA 94550

G.R. Hilst

Electric Power Research Institute

P.0. Box 10412

Palo Alto, CA 94303

Ray Hosker

NOAA/Atmospheric Turbulence and Diffusion Laboratory

P.0. Box E

Oak Ridge, TN 37830

Frank Hudson

Department of Energy

ER-74

Washington, DC 20545

Bill Knuth

Environmental Systems and Service 4895 Gaddy Lane

Kelseyville, CA 95451

Rolf _ange

$L-262$

Lawrence Livermore Laboratory

P.0. 30x 808

Liverinore, CA 94550

Bob Lee

$L-262$

Lawrence Livermore Laboratory

P.0. Box 808

Livernore, CA 94550

Dr. John Leone

L-262

Lawrence Livermore Laboratory

P.0. Box 808

Liverrore, CA 94550 
No. of

Copies

C.J. Nappo

NOAA/Atmospheric Turbulence and Diffusion Laboratory

P.0. Box E

Oak Ridge, TN 37830

W.D. Neff

Wave Propagation Laboratory

NOAA/Environmenta 1 Research Lab

M.S. R45 X7

325 Broadway

Boulder, CO 80303

R. Peters

MS-40

California Energy Commission

1516 9th Street

Sacramento, CA 95814

R.A. Pielke

Colorado State University

Dept. of Atmospheric Sciences

Ft. Collins, CO 80523

K. Shankar Rao

NOAA/Atmospheric Turbulence and Diffusion Laboratory

P.0. Box E

Oak Ridge, TN 37830

D.S. S1 ade

U.S. Department of Energy

Office of Health and Environment Research

MS-ER 74

Washington, DC 20545

M.A. Wolf

Dept. of Atmospheric Sciences

Oregon State University

Corvallis, OR 97331

Dr. R.M. Woods, Jr.

U.S. Department of Energy

Office of Energy Research

MS ER-22

Washington, DC 20545
No. of

Copies

Gene L. Wooldridge

Dept. of Soil Sciences and Biometeorology

Utah State University/UMC-48

Logan, UT 84322

Tetsuji Yamada

Los Alamos National Laboratory MS-D466

P.0. Box 1663

Los Alamos, NM 87545

\section{ONSITE}

DOE Richland Operations Office

H.E. Ransom

28 Pacific Northwest Laboratory

D.B. Cearlock

G.W. Daws on

J.C. Doran

D.W. Dragnich

C.E. Elderkin

R.K. Hadlock

J.M. Hales

T.W. Horst

N.S. Laulainen

M.M. Orgil1

W.T. Penne 11

G.A. Sehme 1

WGN Slinn

J.M. Thorp

L.L. Wende 17

C.D. Whiteman

R.K. Woodruff

Publishing Coordination (2)

Technical Information (5) 


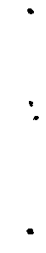

